\title{
Power Types and Measurement of Ideological Work in Universities
}

\author{
Chi Zhang ${ }^{1, *}$ \\ ${ }^{1}$ School of Marxism, Dalian University of Technology, Dalian, Liaoning 116024, China \\ *Corresponding author. Email: zhangchikobe@163.com
}

\begin{abstract}
As an important position of the ideological work for Communist Party of China (CPC), universities take up the heavy responsibility of cultivating and provide talent guarantee and intellectual support for the realization of the Chinese great rejuvenation. This paper studies the power operation of ideological work in university. First, it analyses three power types of leadership, management and discourse in university ideological work, clarifies the relationship among various powers, constructs the theoretical system of power measurement, and finally puts forward the strategy of power improvement in university ideological work.
\end{abstract}

Keywords: university ideological work, leadership power, management power, discourse power

\section{INTRODUCTION}

Under the leadership of the Communist Party of China, the university ideological work should give full play to the role of the Party organizations at different levels in ideological guidance, strengthen the important function of the university as an ideological position, and actively lead the social trend of thought. University ideological work plays an important supporting role to achieve the duties of personnel training, scientific research and social services. The Party committee leadership is the fundamental system of university governance, which provides an important institutional guarantee for the ideological work.

Xi Jinping pointed out: "ideological work is an extremely important work" [1]. Universities must strengthen ideological work. Ideological work is carried out through the operation of leadership power, management power and discourse power. To firmly grasp the power of leadership, management and discourse is a major requirement for ideological work under the new social conditions, and also a strong guarantee for consolidating the leading position of Marxism in the ideological field. Only when we grasp the connotation, scope and intensity of three different kinds of powers and correctly operate them, can we ensure that the ideological work is carried out smoothly, efficiently, and truly implemented. Xi Jinping stressed: "we must firmly grasp the leadership power, management power and discourse power of ideological work in the hands, and we must not drop them at any time." [2]

\section{POWER TYPES OF IDEOLOGICAL WORK IN UNIVERSITY}

Here, we specifically analyze three powers of university ideological work: leadership power, management power, and discourse power.

\subsection{Leadership Power}

In a broad sense, the leadership power of ideological work belongs to a certain class and its political representatives, whose ideology has gained wide social recognition and general approval from various ideological theory competitions and consciously converted into people's political beliefs and political actions, through non-violent ways [3, 4]. According to China's actual situation, this power belongs to Chinese people whose political representative is the Communist Party of China. Specifically, based on its own advanced characteristics, the CPC makes masses of the people accept the theory of Sinicization of Marxism, and puts it into the process of social practice, through the means of economic, political, cultural, legal and ideological propaganda.

The leadership of ideological work helps universities to grasp the direction of ideological construction accurately, consolidate the guiding position of Marxist ideology, and play a good role in the unified construction of socialist ideology. It also provides a legal basis and a right direction for the management power and discourse power of ideological work.

Through historical investigation, we know that there are seven stages in the struggle for leadership power in Chinese universities, showed in Table 1.

When the People's Republic of China was founded in 1949, Chinese universities learned from the experience of the Soviet Union and implemented the "president in charge" system. The most obvious problem of this system was that it did not give prominence to the leadership of the CPC.

After 1956, Chinese universities began to implement the "school affairs committee responsibility system under the leadership of the CPC", which clearly defined the leading role of the Party committee in university government and effectively alleviated the problems of the last system. However, due to the failure of the president's personal 
leadership, the administrative operation in universities was affected to some extent.

In 1964, in order to further straighten out the relationship between the Party Committee and the executive branch in universities, Chinese government improved the university leadership system into "the responsibility system of the school affairs committee headed by the president under the supervision of the Party committee". It laid a good foundation for the implementation of a more perfect university leadership system in the future. During the next ten years, although the national education administration stipulated that the university should implement the unified leadership of the CPC, a relatively stable leadership system has not been formed.

In October 1978, Chinese universities began to implement the "President's responsibility system based on division of labour under the leadership of the Party committee".
In the mid-1980s, Chinese universities gradually implemented the "president in charge" system again, which weakened the leading role of the Party committee in universities.

After 1989, on the basis of summing up the past development experience, the central government issued a law emphasizing that the university should still implement the "president responsibility system under the leadership of the Party committee". As a result, the leadership system of Chinese universities has been fully established.

The practice of university leadership system develops in optimization. This exploration process is not only an indepth reflection on how to allocate the leadership power of universities, but also an internal need to strengthen the university ideological work, which has been constantly developing in the exploration of the leadership system.

Table 1 Historical change of university leadership system (since 1949)

\begin{tabular}{|c|c|c|}
\hline Time & Leadership System & Characteristic \\
\hline $1949-1956$ & President in charge & Easy to break away from the leadership of the party \\
\hline $1956-1961$ & $\begin{array}{c}\text { School affairs committee responsibility system under } \\
\text { the leadership of the CPC }\end{array}$ & $\begin{array}{c}\text { Highlight the leadership of the Party committee in } \\
\text { university. Lack of the role of the president }\end{array}$ \\
\hline $1961-1966$ & $\begin{array}{c}\text { Responsibility system of the school affairs } \\
\text { committee headed by the president under the } \\
\text { supervision of the Party committee }\end{array}$ & $\begin{array}{c}\text { Highlight the leadership of the Party committee in } \\
\text { university. Combination of collective leadership and } \\
\text { president leadership }\end{array}$ \\
\hline $1966-1978$ & Unified leadership of the CPC & $\begin{array}{c}\text { The leading position of the Party committee has } \\
\text { declined. The role of the president is severely limited }\end{array}$ \\
\hline $1978-1985$ & $\begin{array}{c}\text { President's responsibility system based on division of } \\
\text { labour under the leadership of the Party committee }\end{array}$ & $\begin{array}{c}\text { To restore the leadership of the Party committee. } \\
\text { Clear division of work among university leaders }\end{array}$ \\
\hline $1985-1989$ & President in charge & $\begin{array}{c}\text { The leading role of the Party committee in university } \\
\text { has been weakened }\end{array}$ \\
\hline $1989-$ Now & $\begin{array}{c}\text { President responsibility system under the leadership } \\
\text { of the Party committee }\end{array}$ & $\begin{array}{c}\text { Highlight the leadership of the Party committee in } \\
\text { University. Combination of Party committee } \\
\text { leadership and president responsibility }\end{array}$ \\
\hline
\end{tabular}

\subsection{Management Power}

Generally, the management power of ideological work belongs to the dominant class, stratum and political representative in a certain society (usually a political party or a political party alliance in modern countries). In order to realize their own specific interests, they use the management power in forms of planning, organization, command, coordination and control to integrate various resources inside and outside the ideological field, so as to effectively promote the achievement of creative activity process of ideological work.

For universities, it means that the Party committee maintains the guiding position and leading role of the mainstream value of Marxism in the field of ideology in university, and has the authority to manage the people, affairs, finance and resources related to ideology work. It includes organizing and propagating Marxist theory and theory of socialism with Chinese characteristics, inheriting and developing Chinese traditional culture, carrying out ideological education for teachers and students, carrying forward the spirit of patriotism, resisting the adverse effects and threats of foreign thoughts, and maintaining the ideological security within the university campus.

Unlike leadership power, which emphasizes the overall control of ideological theoretical interpretation and value belief, management power focuses more on the specific transformation process from goal to tactics. The object of power operation is various resources related to ideological work in university. This kind of power pursues the optimization of resource allocation and utilization, and emphasizes efficiency.

The management power of ideological work in university needs to improve the relevant management system, clarify the specific management responsibilities of the corresponding posts, implement the "post responsibility system", and achieve the post setting management, legal management, scientific management and effective management together. At the same time, we should also pay attention to the team building of the staff, through strengthening the staff's learning ideological theory, and 
training them how to better carry out ideological management work.

\subsection{Discourse Power}

The word "discourse power" comes from Michel Foucault, a famous French philosopher, who puts forward a view that "discourse is power". Discourse is a kind of "power", an important skill of people's struggle, and a necessary condition for the realization of real power. From the perspective of the Marxism value, the discourse refers to the power which makes Marxism theory obtain a dominant opportunity to spread its content in society by controlling, guiding and standardizing the society with its own position [5]. The discourse power includes the power to question, to judge, to explain and to criticize [6]. A particular class or group fights for this discourse power to spread and publicize its mainstream thoughts, ideas and consciousness in order to maintain its own interests.

The discourse power of ideology work shapes the mainstream ideology of the society and operates in form of cultural input and output. It constantly influences social members' values and behaviours, through spreading ideology in specific language form and criticizing other kinds of opposite social thoughts. It is a national tool to ensure the legitimacy and stability of state power. Under the background of complicated situations at home and abroad, the Communist Party of China must seize the initiative to make a high decibel voice, lead in a diversified and changeable international circumstance, and enhance the cohesion and influence of the Party' s mainstream ideology. The construction effect of university ideological discourse power is related to the value judgment of teachers and students, and it is the key to grasp the ideological leadership in university. Under the leadership of the Party committee, universities should give full play to the important role of teachers, philosophy and social science researchers, counsel and executive staff. They need study and develop in the content of Marxism and Socialist theories with Chinese characteristics, strengthen the explanation of these theories above, promote the integration of traditional and new carriers of discourse communication. Government and universities should both provide institutional and material guarantee for the construction of discourse power in university, meanwhile social organizations outside university could better provide material supplement.

\section{RELATIONSHIP OF THREE POWERS}

The operations of leadership power, management power and discourse power of ideological work in university are not completely independent. In university ideological work, three kinds of power act as the same subject in different levels and scopes, form a balance state of mutual connection and coordination, which guarantees the completion of the unified goal of university ideological work.

Leadership power is the foundation of ideological work, which provides legitimacy support for management power and discourse power. Management power is the realization process of leadership, which achieves through the operation and implementation of all kinds of resources related ideological work, such as policy, finance, materials, team, personnel and various theoretical materials. The discourse power is the concrete embodiment of the combination of the legal basis of leadership and the implementation results of management power, which directly reflects the expression mode and content of ideological work. Therefore, the relationship among leadership power, management power and discourse power shows the logic of "foundation and goal (dual) - execution process - presentation results". The power of leadership, management and discourse are performed together at the same time, while there is also a selfcirculation process of "leadership - management - discourse - leadership" in the internal power relationship structure.

\section{MEASUREMENT OF THREE POWERS}

When considering measuring the content system of ideological power in university, the McKinsey $7 \mathrm{~S}$ model is introduced because the follow-up research also involves the issue of power evaluation. The evaluation dimension is included in the content of power measurement, and the three-dimensional system of "power type - ideological work content - McKinsey 7S Model" is constructed.

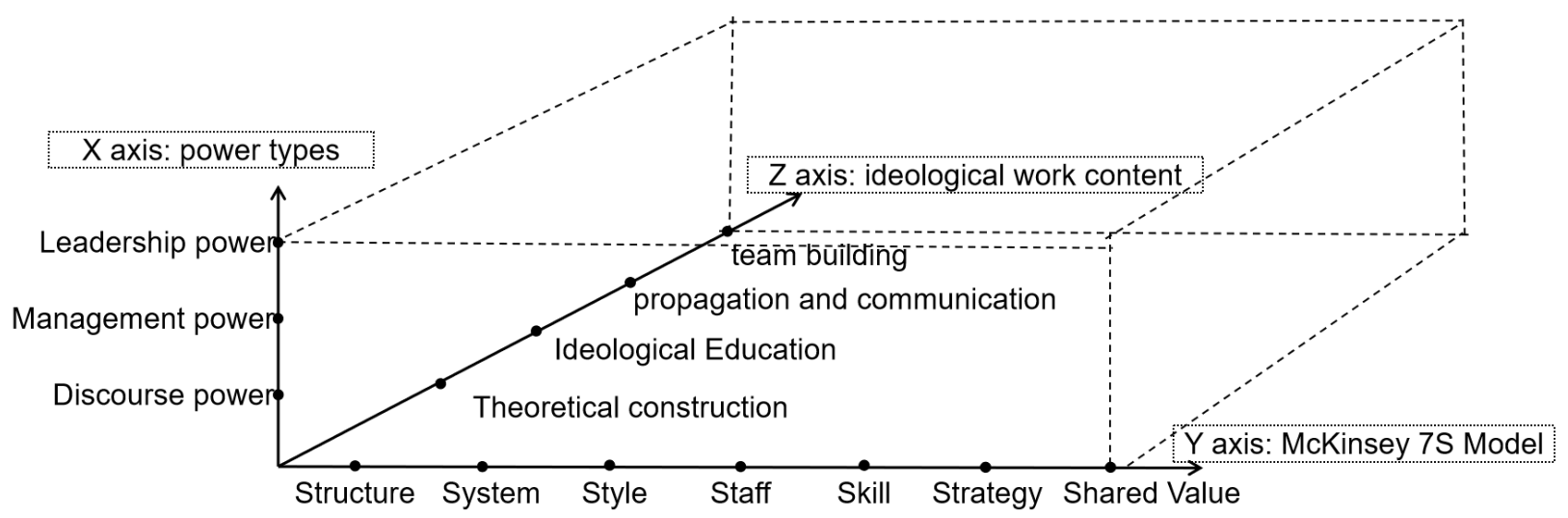

Figure 1 The measurement dimensions of university ideological work 
In this measurement system showed in Figure 1, the first dimension (x-axis) is the power types, which is divided into three levels of leadership power, management power and discourse power as the analysis above. The second dimension (Y-axis) introduces McKinsey 7S Model. McKinsey 7S Model is the seven elements of enterprise organization designed by the research center of McKinsey Consulting Company. It points out that organizations must consider all aspects in the development process, including structure, system, style, staff, skills, strategy and shared value [7]. The third dimension ( $\mathrm{Z}$-axis) is the ideological work content. According to literatures, the specific issues of ideological work in university are divided into four aspects: theoretical construction, ideological education, propagation and communication, and team building.

In the specific design of the questionnaire items, we should put forward questions from the perspective of the participants' feelings and cognition, so that they can understand the questions more easily and make real responses. Measurement based on perception of participants can scientifically and accurately reflect the actual utility results of ideological work power operation.

\section{OPTIMIZATION OF IDEOLOGICAL WORK POWERS IN UNIVERSITY}

In a new situation, the ideological work in Chinese universities faces not only precious opportunities for development, but also some obvious problems that need to be solved. For example, in the university ideological work, the guiding effects of the theory of socialism with Chinese characteristics is insufficient in practice; the vitality of the basic Party organizations in university needs to be further enhanced; the education mode of the socialist core values for teachers, staff and students is not innovative; the personnel system in ideological work, such as training, selection, management, reward and punishment, is not perfect, etc.

In the new era, to optimize power of university ideological work, we should pay attention to the following aspects.

First, we should further give full play to the leading role of the Party committee in university. Secondly, we should strengthen the theoretical guidance and adhere to the leading position of Marxism. Give full play to the specific guidance of the theory for the university ideological work practice. Third, we should continue to strengthen the construction of grass-roots Party organizations. Universities should combine the characteristics of the times and the actual ideological situation of teachers and students to improve the methods of education and management for their members. Four, based on the characteristics of the Party organizations at the grassroots level, we should vigorously innovate the carriers and ways of the Party branches' activities, effectively enhance the vitality and creativity of the Party grass-roots organizations. In addition, we should strictly implement the responsibility system of ideological work; build a new internet propaganda platform for the expression and communication of ideological discourse power; and strengthen the cultivation of talents in theoretical and practical fields of ideological work.

\section{CONCLUSION}

In this paper, the connotation, relationship structure, measurement system and optimization strategy of three powers of ideological work in university are studied. On the theoretical level, from the perspective of power, it deepens researches of university ideological work and provides rich analysis framework, thinking method and content material for theoretical innovation. On the practical level, it can provide evaluation basis for the power operation of the ideological work in Chinese universities, help to find problems in the ideological work and solve them in time, and ensure the correct and efficient exercise of three powers in university ideological work.

\section{ACKNOWLEDGMENT}

This work was supported by National Social Science Foundation of China (18CKS045), and Liaoning Economic Social Development Fund(20191slktqn-065).

\section{REFERENCES}

[1] J.P. Xi, Holding the overall situation in mind, focusing on major issues and striving to do better in propaganda and ideological, 2013 National Conference on propaganda and ideological work, information on HTTP://cpc.people.com.cn/n/2013/0821/c6409422636876.html

[2] J.P. Xi, Jinping Xi's Excerpts on the Construction of Socialist Culture, Central Literature Press,2014.

[3] L. Li: The basic connotation and connection of ideological leadership, management and discourse power, Academic Forum, Vol. 40 (2017) No.04, p.119.

[4] Z.L. Qing, Y. Wang: Research on the relationship among ideological power of leadership, management and discourse, Ningxia Social Science, (2017) No.06, p.17.

[5] J. Zhang, W.J. Shen: Research on challenge and Realization of the discourse power of Marxist ideology in ideological propaganda in China, Contemporary World and Socialism, (2011) No.01, p.163.

[6] H.Q. Hou: Research on the discourse power of ideology, Studies on Marxism, (2014) No.12, p.5.

[7] Information on

HTTP://strategicmanagementinsight.com/tools/mckinsey7s-model-framework.html 